\title{
THE BOARD WORK EXPERIENCE DIVERSITY AND THE PERFORMANCE OF RUSSIAN COMPANIES
}

\author{
I. V. DERGUNOVA, T. G. DOLGOPYATOVA \\ Institute for Industrial and Market Studies, National Research University \\ Higher School of Economics, Russia
}

\begin{abstract}
The goal of this study is to empirically assess the influence of the board of directors' work experience diversity on the performance of Russian non-public companies. The board work experience diversity is measured by the diversity index proposed by the authors, as well as by the number of work experience types and categories. Russian boards are characterized by a low level of diversity, directors with work experience in the same company prevail, on the second and third places are the experience in other enterprises in the industry and the experience in the group of related companies. It has been established that there are no prevailing combinations of experience in industrial companies. A positive influence of the directors' work experience diversity on the increase of companies' return on capital from 2017 to 2019 was found. The analysis is based on the data from a 2018 survey of industrial managers conducted by the Higher School of Economics.
\end{abstract}

Keywords: experience diversity, firm performance, corporate governance, the board of directors.

JEL: G32, G34, M14.

\section{INTRODUCTION}

There are different approaches to the analysis of the activities of boards of directors (BoD): researchers look at the composition of the boards, their functions and areas of activity. Evaluating BoD performance is essential for the understanding of the corporate governance and its impact on the functioning of companies. L. Zingales notes the increased influence of human capital on company value [Zingales, 2000]; people can

The article was prepared as a part of the work on the topics of the HSE Basic Research Program "Effectiveness factors and directions of competitiveness improvement for Russian manufacturing enterprises under current conditions" (2020) and "The competitiveness of Russian industry: factors stimulating the activity and growth of enterprises" (2021). The article is based on the materials of the report presented at the $7^{\text {th }}$ International GSOM Emerging Markets Conference 2020.

Postal address: 18, Myasnitskaya ul., Institute for Industrial and Market Studies, National Research University Higher School of Economics, Moscow, 101000, Russia.

(c) I. V. Dergunova, T. G. Dolgopyatova, 2021

https://doi.org/10.21638/spbu18.2021.101 
have a particularly strong influence on the performance of an enterprise when they are at the top level of the company's management, which includes the BoD [Fich, 2005]. For example, in a recent work, R. Hauser showed a significant impact of changes in the composition of the board of directors on the value of an enterprise using the example of companies that have gone through the processes of mergers and acquisitions [Hauser, 2018].

To assess the corporate governance in different time periods, researchers studied BoD from the point of view of agency theory [Jensen, Meckling, 1976], resource dependence theory [Pfeffer, Salancik, 1978; Zahra, Pearce, 1989], institutional theory [DiMaggio, Powell, 1983], social relations theory [Granovetter, 1985], and stewardship theory [Davis, Schoorman, Donaldson, 1997]. In modern literature, researchers distinguish two main areas of activity of the board of directors - monitoring the activities of top management related to the agency theory and expert assistance to the manager and the owners related to the resource approach [Adams, Akyol, Verwijmeren, 2018; Dass et al., 2014; Drobetz et al., 2018]. These roles are not mutually exclusive; moreover, in successful companies, boards should combine both roles, since the knowledge and expertise of directors, allowing them to perform the resource function, also helps improve councils' understanding of available information and facilitate monitoring of top management's actions [Hermalin, Weisbach, 2003; Adams, Ferreira, 2007; Brickley, Zimmerman, 2010].

Quite naturally, a question arises about the different work experience of directors, how it helps to perform a certain function and to combine assistance and monitoring tasks due to the diverse experience of BoD members. In addition, it is necessary to look at whether there are combinations of work experience that help directors in their actions in different directions, and whether different skills complement each other or, on the contrary, they interfere.
The goal of the study is to empirically assess the impact of the board of directors' work experience diversity on the performance of Russian non-public companies, which can only be done using survey data, but not using the small number of available issuers' reports. Following the work of [Adams, Akyol, Verwijmeren, 2018], it is assumed that there is no prevailing experience or its combinations that provide better performance of companies. Further, the survey data is used to verify the previously obtained results of studies of the influence of different combinations of the directors' experience [Anderson et al., 2011; Knyazeva, Knyazeva, Raheja, 2013; Adams, Akyol, Verwijmeren, 2018; Bernile, Bhagwat, Yonker, 2018]. In the previously mentioned papers, data of public companies was used; they examined the influence of a variety of directors' experiences on market assessment of firms' performance, such as the Tobin coefficient. This study deals mainly with non-public industrial companies, the owners of which seek to increase the profitability of their investments in the company, therefore, the dependent variable is not the value of companies, but the return on capital of these companies. For hypotheses, it is assumed that the diversity of directors' work experience has a positive effect on the return on capital and that there are no prevailing combinations of work experience inherent in all companies in the sample.

The analysis is based on the data from a survey of industrial managers conducted by the Higher School of Economics in 2018. The survey covered 1716 companies in 20 sectors of economic activity, which were then aggregated into 9 manufacturing industries, and included 635 companies (both joint-stock companies and limited liability companies), the top management representatives of which confirmed the presence of BoD. Calculations were based on unweighted data. To obtain consistent statistical results, several data analysis methods were used: factor analysis, a linear OLS regression, binary choice models (probit model).

PЖM 19 (1): 5-34 (2021) 
The article includes three sections. The first section covers contemporary empirical research of the influence of different work experience and qualities of directors on the firm performance. The second section describes the research methodology, including a description of hypotheses, data, methods, and models used. The third section presents the results of empirical studies, including factor analysis of relationships between types of work experience and regression estimates of the impact of the work experience diversity of the board of directors on the companies' return on capital. In conclusion, we will summarize the results of the analysis.

\section{LITERATURE REVIEW}

A large number of empirical studies of the influence of directors' certain qualities and skills on the performance of companies show mixed results. In general, the following estimates of the impact of industry experience on the value of publicly traded companies are based on data from US firms (unless otherwise noted). N. Dass with coauthors [Dass et al., 2014] believe that the directors' experience in a related industry (from the supplier or consumer side) is one of the main factors for successful corporate governance and growth of company value. The effect is especially significant when information asymmetries are present, as this work experience helps to overcome industry shocks and shorten the working capital cycle. Researchers believe that experience in related industries brings significant gaps in knowledge about these industries to the BoD, as well as the necessary connections with participants in related markets. It is this knowledge that makes it possible to predict market conditions and trends, which allows to better use the factors of production and avoid shocks from suppliers or consumers. W. Drobetz with coauthors [Drobetz et al., 2018] come to similar conclusions: it is the industry experience of independent directors that allows boards to do both monitoring and their resource function better. In this paper, researchers have shown the positive impact of the proportion of independent directors with industry experience on the value of industrial companies included in the S\&P1500 index.

In contrast to the aforementioned works, S. Kang with coauthors note the importance of industry experience only in combination with experience as a chief executive officer (CEO). According to the authors, only a combination of a general management understanding of business operations and specific industry knowledge allows a board member to define and implement a company's growth strategy. Otherwise, if the director has industry experience only, he will not be able to fulfill his or her resource function, since, without the effective communication experience and a deep understanding of the "political" situation within the board, the director will not be able to convey his or her view on the situation [Kang, Kim, Lu, 2018].

CEO experience also has a mixed effect on a company's performance. In a 2005 paper, Fich shows that in successfully growing companies, there are members of the board of directors who serve as the CEO of another company [Fich, 2005]. During the event study, the author demonstrates that the inclusion of another company's executive in the board of directors leads to the cumulative abnormal return of the stock of the given enterprise. Thus, the managerial experience of an outside director is viewed as unique expertise that adds value to the company. In [Fahlenbrach, Low, Stulz, 2010] the results turned out to be the opposite - the authors could not reject the hypothesis that managerial experience (as a CEO in other enterprises) had no influence on the company's operating performance indicators. In particular, the authors were unable to identify the positive impact of CEO experience on board decisions such as changing CEOs, taking over another firm, or determining CEO compensation.

Contradictory results are shown in studies of the independence of directors on boards. According to theoretical assumptions, the 
directors' independence can lead to both an increase and a decrease in the company's performance. Improved monitoring of management actions, reduced likelihood of collusion, and greater opportunities in terms of directors' connections, resources, and skills are seen as the main benefits of directors' independence. The drawback of a larger proportion of independent directors may be the lack of understanding and interaction within the board. In the study [Cavaco et al., 2017], which was done based on French company data, it was shown that the factor of independence itself negatively affects the performance of the company, although the effect decreases if the director has expertise in this industry. The authors attribute this effect to the informational deficit that independent directors face since the executive director will not necessarily share company-specific data. In contrast, one study of firms in developing countries showed a positive relationship between the power of an independent director and firm value [ $\mathrm{Zhu}$ et al., 2016].

The presence of directors' financial expertise also does not give a clear effect. On the one hand, in theory, the presence of financial expertise allows the BoD to receive additional information about the risks of financial transactions, which contributes to better performance of the top management monitoring function. On the other hand, information about government guarantees for the banking system allows directors to put pressure on top management and make riskier decisions if it is in the interests of shareholders [Minton, Taillard, Williamson, 2014]. A study [Güner, Malmendier, Tate, 2008] shows that the presence of financial experts in the BoD increases access to loans, especially for banks that are closely associated with expert directors. However, in most cases, enterprises with less financial constraints and worse opportunities get access, which the authors explain by the actions of the lending bank. A more recent work [Minton, Taillard, Williamson, 2014] found that the presence of financial experts on the boards significantly worsened the performance of companies in the financial sector during the 2007-2008 crisis. Firstly, researchers associate this with knowledge of complex financial instruments and their habitual use by financial experts, which leads to higher risk-taking. Another potential explanation is that financial experts represent the interests of shareholders and understand the residual nature of their claims, which leads to participation in projects with excessive risk.

The political experience of directors also has different impacts on the company's value. A. Agrawal and C. Knober argue that directors with experience in politics play a large role on the boards of governmentaffiliated companies, for example, if the company is involved in public procurement processes or if the government is actively regulating the market. The authors also show that in the American manufacturing industry in the $1990 \mathrm{~s}$, the importance of politically experienced directors increased with increased market competition [Agrawal, Knoeber, 2001]. E. Goldman and coauthors obtained interesting results when analyzing companies from the S\&P500 list - with a Republican director on the board and no directors with opposing political views, the company's value increased after a Republican won the presidential election. Companies with Democratic directors, on the other hand, showed negative cumulative excess returns on stocks. Researchers also found positive investor reactions and rising company values in response to news of the appointment of a politically experienced director [Goldman, Rocholl, So, 2009]. On the contrary, the negative influence of the political preferences of directors on the company's value was found in the study [Lee, Lee, Nagarajan, 2014]. In this work, the researchers developed an index of the similarity of political preferences of board members and the companies' top management and showed that high similarity in political views leads to lower performance of companies, weaker compensation schemes, and an increased likelihood of fraudulent schemes within corporations.

PЖM 19 (1): 5-34 (2021) 
In this study, we do not consider gender diversity issues. However, in the modern literature on corporate governance, there are many studies devoted to this topic. This is largely due to the changing legal regulation of corporate governance, according to which in some developed countries the board of directors should have a certain minimum percentage of women directors. The conflicting results of Western studies can be found in the works [Adams, Ferreira, 2009; Cruz et al., 2019], for Russian companies a detailed analysis is presented in [Garanina, Muravyev, 2018].

Based on a number of studies, only one general conclusion can be drawn - the influence of work experience or certain skills of directors cannot be considered in isolation from other factors. The contradictions in the results can be explained by the mutual influence of factors - the ability of one skill to influence the company's performance depends on the presence of other qualities of the board members [Adams, Akyol, Verwijmeren, 2018; Knight et al., 1999; Pelled, Eisenhardt, Xin, 1999]. In the literature, there are two explanations for the mutual influence. On the one hand, having similar qualities and skills simplifies the interaction between directors, but they may lack an alternative approach and points of view to make effective decisions. On the other hand, having different experience on boards allows companies to be more productive and identify better solutions to a problem, but overly different experience can lead to misunderstandings and controversy [Murray, 1989; Milliken, Martins, 1996]. For example, in a 2017 theoretical paper, L. Garlappi, R. Giammarino and A. Lazrak showed that the current diversity in an investment decisionmaker seriously increases the likelihood of future disputes between agents, which in turn leads to rejection of good investment opportunities [Garlappi, Giammarino, Lazrak, 2017]. Differences in the skills and experience of directors can also significantly lengthen the decision-making period, leading to inefficiency [Hambrick, Cho, Chen, 1996].
Since the skills of directors influence each other, some researchers propose to evaluate the multidirectional effects of characteristics of board members through a common indicator of diversity. The results of such studies are also highly controversial. A study by R. Anderson and coauthors shows both multidirectional effects. On the one hand, in American industrial companies with a complex organizational structure a greater variety of directors' qualities, skills and experience leads to better monitoring of the actions of top management and positively affects the assessment of companies by investors. On the other hand, an excessive variety of qualities of board members leads to conflicts and negatively affects the value of companies in companies with a simpler structure. Interestingly, a firm's performance is more influenced by the diversity of work experience and education than by age, ethnicity, or gender ratio within boards [Anderson et al., 2011]. In an empirical study in 2013, A. Knyazeva, D. Knyazeva and C. Raheja showed a negative impact of the diversity of the qualities of directors on the value of companies, which was explained by the lack of focus on the boards [Knyazeva, Knyazeva, Raheja, 2013]. R. Adams, A. Akyol and P. Verwijmeren found a negative impact of diversity on company performance [Adams, Akyol, Verwijmeren, 2018], while G. Bernile and coauthors noted a significant positive effect of greater diversity in the qualities of directors and the absence of any influence of factors separately [Bernile, Bhagwat, Yonker, 2018].

This paper examines the relationship between the experience of directors and the performance of Russian companies, therefore the findings of some of the few studies on Russia should be mentioned which are more focused on the resource function of BoD. T. Dolgopyatova with coauthors found an increasing influence of the board of directors in a large Russian public company associated with changes in the economic conditions and the transformation of the company's business model [Dolgopyatova et al., 2015a; 2015b]. With the help of a case study, the authors 
identified the role of directors' contribution to the development of the company, especially when making strategic decisions.

The influence of various characteristics of board members in Russian companies, including non-public ones, was analyzed in [Dulyak, 2015]. The author tried to assess the influence of such factors as the directors' experience in government bodies, experience in foreign companies, the proportion of directors with higher education, and the age of the BoD chairman. Empirical analysis showed no relationship with firm performance, despite the theoretical arguments. Perhaps this is an illustration of the influence of the factor of diversity, which was considered by M. Benkewitz, R. Adams, and other authors [Bankewitz, 2016; Adams, Akyol, Verwijmeren, 2018]. At the same time, $\mathrm{Yu}$. Dulyak confirmed the hypothesis of a positive relationship between experience in this industry and the company's performance, as well as the hypothesis of the positive impact of the share of executive directors [Dulyak, 2015]. Another interesting result related to the participation of the current $\mathrm{BoD}$ chairman in the management of another company: the author revealed a negative relationship with the firm's activities, which is similar, for example, with the results of Hauser's study [Hauser, 2018].

A. Muravyev identified the main structural characteristics of the board for public Russian companies and assessed their impact on the performance of the companies. There was no statistically significant effect of the BoD size and the average age of board members on the performance indicators. The influence of the proportion of directors affiliated with the company and directors with political connections was also not found. However, an increase in the share of foreign directors had a positive effect on the ratio of market value to accounting value [Muravyev, 2017].

In a recent paper based on data from Russian companies, I. Berezinets, Yu. Ilina and A. Loginova investigated the impact of social capital of the board of directors, company size, and board size on company performance. As various characteristics of social capital, the average number of positions held by a director in the BoD of other companies is used, including separately calculated for executive, non-executive, independent, and affiliated directors. The authors concluded that an increase in the participation of directors in the board of directors of other companies negatively affects the performance of companies since this factor is directly related to the employment of the director and his or her limited opportunities for effective participation in the company's management, which in turn leads to a negative impact on its financial indicators. It is interesting that the participation of a director in the BoD of other companies in the past, on the contrary, has a positive effect on indicators. Berezinets and coauthors explain this from the point of view of the resource theory the established connections and acquired experience contribute to further access to important opportunities and resources, which reduces the company's transaction costs [Berezinets, Ilina, Loginova, 2019].

A 2020 survey of boards of directors in mid-sized Russian companies revealed interesting changes in corporate governance. Compared to 2015, the owners of non-public companies have an increased interest in creating a board of directors, partly due to the desire to obtain an alternative independent point of view and transfer operational management to professional managers. Besides, tendencies of a decrease in the concentration of ownership and an increase in the role of councils were revealed [Research of corporate governance practices..., 2020].

\section{RESEARCH METHODOLOGY}

\subsection{Hypotheses and data}

As discussed above, the impact of different experience types varies from significantly

PЖM 19 (1): 5-34 (2021) 
positive to significantly negative, depending on the specifics of the activities of public companies and external conditions. In this regard, it is assumed that the availability of different work experiences will depend on the needs of the business for non-public companies as well, which - due to the complexity of obtaining data - have hardly been studied previously.

Some boards may have directors with multiple work experience, while others do not. Depending on the companies' characteristics, some work experience may cluster, however, no prevailing combinations of work experience are expected in Russian non-public companies. Then the main dimension of variation between different work experience is their diversity.

H1. There is no prevailing work experience and no prevailing work experience combinations in Russian industrial companies.

L. Zingales notes that in modern companies all stakeholders have influence, not just the main shareholders. The main task of corporate governance is to prevent conflicts between influence groups, otherwise, the company's value is destroyed [Zingales, 2000]. When studying the reasons for creating a board of directors in Russian non-public companies, the requirements of creditor banks and access to the contacts of directors were identified [Research of corporate governance practices..., 2020]. Board members should take into account the interests of all stakeholders, seek a compromise between solutions. To do this, you need to have a variety of skills and work experience. All other things being equal, in successful companies, having more stakeholders should lead to a more diverse directors' work experience, that is, the relative level of diversity will be higher.

The companies included in the study are non-public, therefore, we will consider companies in which the return on capital is higher than the average for this sector as more successful.

H2. The degree of relative work experience diversity of the BoD is positively associated with companies' return on capital.
The empirical study will use several control variables to assess the net effect of the relative diversity of work experience on enterprise profitability. In the literature that analyzed the role of BoD in companies, the model often includes indicators of company size (logarithm of sales, the logarithm of the number of employees), industry dummy variables, and the number of years since the company was founded [Adams, Ferreira, 2009; Cavaco et al., 2017; Bernile, Bhagwat, Yonker, 2018; Kang, Kim, Lu, 2018; Garanina, Muravyev, 2018]. Some researchers also suggest taking into account the presence of a foreign owner [The New Economic School..., 2010]. The importance of combining ownership and management is also noted when considering Russian enterprises [Berezinets, Ilina, Cherkasskaya, 2013].

The age of an enterprise affects the performance of companies in different ways [Linck, Nettera, Yang, 2008; Kang, Kim, $\mathrm{Lu}, 2018]$. The size of the enterprise and the number of markets in which the company is represented reflect the complexity of a business organization, which is advisable to control when assessing the role of the board of directors. From one point of view, foreign ownership may have a negative impact on Russian companies' performance due to economic sanctions in 2014 which led to capital outflow. The introduction of sanctions accelerated the policy of import substitution in the Russian Federation, it led to more strict requirements for the localization of production of foreign companies in Russia, which in turn had an effect on the volume of state support. At the same time, the localization above a certain level may lead to additional costs, problems with quality and demand. From another point of view, A. Muravyev showed a positive effect of increase in foreign directors share in the BoD for public Russian companies [Muravyev, 2017]. The combination of ownership and management may have a positive effect on the firm performance since it helps to eliminate agency problems and enables faster decision making in unstable conditions. The positive 
relationship between combined ownership and control and Russian industrial firm competitiveness [Dolgopyatova, 2011] and positive relationship between executive and non-executive director ownership and public companies' performance [Muravyev, Berezinets, Ilina, 2014] were shown.

The main data source is the database of the survey of manufacturing enterprises top management conducted by the Institute for Industrial and Market Studies (IIMS) of the National Research University Higher School of Economics (NRU HSE) in 2018 (the fourth round of the Monitoring of the Competitiveness of Russian Enterprises), supplemented by the IIMS specialists with the financial and economic indicators of enterprises from the RUSLANA database. As part of the survey, more than 1700 companies were selected from more than 100000 enterprises in the general population with 10 or more employees to conduct formalized face-to-face interviews with top management representatives ${ }^{1}$. The sample is stratified, zoned, with control of size groups, which ensured the representativeness of the general population in the context of size groups in terms of the number of employees and 20 types of economic activity (All-Russian Classifier of Types of Economic Activity codes from 10 to $33^{2}$, the distribution of companies is presented in Appendix, Figures 1 and 2). In this sample, 635 non-public companies were noted to have a BoD: near $37 \%$ of respondents had a position of CEO or executive director, about $51 \%$ were presented by directors or deputy directors on economic or financial issues, and $3 \%$ of respondents were members of the company management body. More than $65 \%$ of all representatives were members of BoD.

1 The text of survey questionnaire can be found on the HSE University website. URL: https://iims. hse.ru/rfge/meth (accessed: 09.11.2020).

${ }^{2}$ All-Russian Classifier of Types of Economic Activity codes can be found on the Federal State Statistics Service website. URL: https://rosstat.gov. $\mathrm{ru}$ /classification (accessed: 09.11.2020).
For each company the interview with one of the top managers was conducted, survey questionnaire was available before the interview upon request. In the survey, managers named groups of influence (stakeholders) that have a significant impact on the formation of the board composition, and also pointed out the experience of board members in different structures (in the company, government bodies, this industry, in the field of entrepreneurship) and highlighted areas of activity, which the BoD has a significant impact on (that is, the main tasks solved by the board).

\subsection{Variables and descriptive statistics}

The database consists of observations of 602 companies, for which respondents noted the presence of different categories of directors' work experience over the past 10 years (33 respondents or $5.2 \%$ found it difficult to answer). Since there is no data on the size of the company's board and the work experience of individual directors, the board of directors is considered as a whole, the collective experience of the board is analyzed (Table 1).

The survey data showed that directors with work experience in the same company prevail - it was noted by representatives of 504 companies out of 602 (33 respondents refused to answer). On the second place is work experience in other companies in the industry, on the third place is work experience in the group of related companies. Regarding the number of types of work, more than half of the companies have directors with only one work experience (348 companies out of $602)$, another quarter has directors with two types of experience. At the same time, out of 155 companies who noted two types of work experience, about $40 \%$ noted work experience in the same company and other companies in this industry, $27 \%$ noted work experience in the same company and in a group of related companies, almost $15 \%$ noted work experience in the same company and in another industry.

PЖM 19 (1): 5-34 (2021) 
Table 1

BoD collective work experience of companies

\begin{tabular}{|c|c|c|c|c|c|c|c|c|c|c|}
\hline \multirow{2}{*}{ Work experience type } & \multicolumn{9}{|c|}{ Number of work experience types } & \multirow{2}{*}{$\begin{array}{c}\text { Total } \\
\text { number of } \\
\text { companies * }\end{array}$} \\
\hline & 1 & 2 & 3 & 4 & 5 & 6 & 7 & 8 & 9 & \\
\hline In the company & 280 & 134 & 72 & 15 & 1 & 1 & 0 & 0 & 1 & $504(83.7)$ \\
\hline $\begin{array}{l}\text { In the group of related } \\
\text { companies }\end{array}$ & 22 & 50 & 38 & 11 & 1 & 1 & 0 & 0 & 1 & $124(20.6)$ \\
\hline $\begin{array}{l}\text { In other companies in the } \\
\text { industry }\end{array}$ & 24 & 74 & 60 & 14 & 1 & 1 & 0 & 0 & 1 & $175(29.0)$ \\
\hline In other industries & 7 & 33 & 35 & 14 & 2 & 1 & 0 & 0 & 1 & $93(15.4)$ \\
\hline $\begin{array}{l}\text { In federal legislative or } \\
\text { executive authorities }\end{array}$ & 1 & 2 & 8 & 1 & 1 & 0 & 0 & 0 & 1 & $14(2.3)$ \\
\hline $\begin{array}{l}\text { In regional / municipal } \\
\text { executive or legislative } \\
\text { authorities }\end{array}$ & 4 & 1 & 7 & 0 & 1 & 0 & 0 & 0 & 1 & $14(2.3)$ \\
\hline $\begin{array}{l}\text { In the law enforcement, } \\
\text { military or security agencies }\end{array}$ & 0 & 1 & 1 & 0 & 0 & 1 & 0 & 0 & 1 & $4(0.01)$ \\
\hline $\begin{array}{l}\text { In entrepreneurship or } \\
\text { management of other } \\
\text { companies }\end{array}$ & 10 & 12 & 16 & 5 & 2 & 1 & 0 & 0 & 1 & $47(7.8)$ \\
\hline $\begin{array}{l}\text { In activities that are } \\
\text { socio-political, scientific, } \\
\text { educational }\end{array}$ & 0 & 3 & 3 & 0 & 1 & 0 & 0 & 0 & 1 & $8(1.3)$ \\
\hline $\begin{array}{l}\text { Total companies that noted } \\
\text { the number of types of expe- } \\
\text { rience }\end{array}$ & 348 & 155 & 80 & 15 & 2 & 1 & 0 & 0 & 1 & 602 \\
\hline
\end{tabular}

N ot e: * column reports the absolute number of answers and the proportion of positive answers (in brackets, \%).

In other words, one can see a shift in work experience towards insider experience and a low level of work experience diversity in the BoD of Russian industrial companies. The average board had 1.63 types of experience (the median is 1 ).

Some of the work experience types give the director similar competencies and skills. For example, work experience in the company and a group of related companies provides a similar understanding of the processes of this business, specific knowledge of a particular company, its strengths, and weaknesses. Work experience in other companies in the industry provides an additional understanding of the specifics of the industry, a similar understanding gives experience in related industries. Experience in various government bodies reflects the need or desirability of interacting with government representatives at various levels. Finally, both managerial experience and socio-political and educational experience intersect when the ability to organize a large number of different people for a well-coordinated work is required. In this regard, all 9 types of work experience can be grouped into 4 categories: (1) insiders (experience in the company and the group of related companies); (2) external industrial experience (in this industry and another); (3) experience in government bodies (federal, regional and municipal, law enforcement agencies); (4) organizational experience (managerial experience and experience in socio-political, scientific and educational, etc. activities). The experience categories mean in the sample is 1.40 (the median is 1 ). 
Based on the survey data, three indicators of the work experience diversity were calculated: the number of types of experience in the company's board of directors, the number of categories of experience, and diversity index based on the HerfindahlHirschman index proposed by the authors. When calculating the diversity index for each category, "saturation" was taken into account, that is, the share of the presented experience in this category. At the same time, the diversity index takes into account the "bias" towards any category of work experience through the introduction of a correction factor $k$.

The formula of the proposed index is the following:
$I=\left(\left(\frac{\begin{array}{c}\text { Number of insider } \\ \text { experiences }\end{array}}{2} \cdot k\right)^{2}+\left(\frac{\begin{array}{c}\text { Number of external } \\ \text { experiences }\end{array}}{2} \cdot k\right)^{2}+\right.$

$\left.\left(\begin{array}{c}\begin{array}{c}\text { Number of } \\ \text { experiences in } \\ \text { government bodies }\end{array} \\ 3\end{array} k\right)^{2}+\left(\frac{\begin{array}{c}\text { Number of } \\ \text { organizational } \\ \text { experiences }\end{array}}{2} \cdot k\right)^{2}\right)$.

Number of non-zero

categories)

where $k$ is a correction factor.

Below (in Table 2) a comparison of all combinations of work experience categories, diversity index and the number of work experience types found in 602 industrial companies are presented (see the box for an explanation of the index calculation).

\section{Explanations for the calculation of the director's work experience diversity index}

With a single type of work experience (combinations from 1 to 4 ), the diversity index is not of particular interest, since in the case of one BoD work experience, the "saturation" of experience in a certain category is almost the same (except for experience in the third category of "authorities", the maximum number in which is three). However, for the two experiences, the differences between companies become visible. For example, in the case of a combination of 5 in the company's board of directors, there are 2 types of work experience in the first category: experience in the company and experience in a group of related companies. For combination 6, there are two experiences in the BoD in the second category: experience in this industry and others. In terms of diversity, such combinations should yield the same index value, since companies have directors with only one category of work experience. Combination 7 gives a more diverse experience and a higher index value: there are directors with insider experience and experience in government. With an increase in the number of types of work experience in the $\mathrm{BoD}$, the difference between the diversity index and the number of experience types increases. Consider combinations 22 through 25 that correspond to the same number of director experience types. The combination 22 uses two types of insider experience and two types of industrial experience. The 23-rd and 24-th reflect more diversity as they represent three categories of experience: insider, industrial, and organizational. The highest variety for 4 types of work experience is presented for a combination 25 - this company has directors with experience in each of the four categories. In general, an increase in the number of types of board work experience speaks of diversity, but in the case of similar types of experience, the diversity index gives more information.

When constructing the index, an assumption was made about the degree of diversity. For example, combinations 6 and 7 represent two work experiences, but combination 6 represents only industrial experience, and combination 7 represents experience in two categories. For this study, it was assumed that combination 7 has a higher degree of di- 
versity than combination 6 . For this, a correction factor $(0.8)$ was introduced into the diversity index formula, which reduces the contribution of the more concentrated experience. For example, the maximum number of work experience types in the category of insider experience is two - experience in the company and experience in a group of related companies. If only one of them is represented in the company, the saturation of experience in this category is $1 / 2$. If both types of experience are represented in the company, then the saturation for this category is $0.8=2 / 2 \times 0.8$. Similarly, if in the category of work experience in government bodies there are two types of experience out of three possible, then the saturation of experience in this category is $2 / 3$; if there are three types of work experience in government bodies, then the saturation is $0.8=3 / 3 \times 0.8$. The choice of the value of the correction factor is due to the value of saturation - the maximum saturation should be less than one $(2 / 2$ or $3 / 3)$, but above the average saturation $(1 / 2$ or $2 / 3)$. Thus, for this study, it was possible to use any value from $2 / 3$ to 1 (we took a coefficient of 0.8 ).

Table 2

Combinations of work experience, diversity index and the number of work experience types presented in the BoD

\begin{tabular}{|c|c|c|c|c|c|c|c|c|}
\hline \multirow{2}{*}{$\begin{array}{c}\text { Combination } \\
\text { number }\end{array}$} & \multicolumn{4}{|c|}{ Work experience category* } & \multicolumn{2}{|c|}{ Diversity index } & \multicolumn{2}{|c|}{ Number of work experience types } \\
\hline & 1 & 2 & 3 & 4 & Value & Frequency & Value & Frequency \\
\hline 1 & 0 & 0 & 1 & 0 & 0.028 & 5 & \multirow{4}{*}{1} & \multirow{4}{*}{348} \\
\hline 2 & 0 & 1 & 0 & 0 & \multirow{3}{*}{0.063} & \multirow{3}{*}{343} & & \\
\hline 3 & 1 & 0 & 0 & 0 & & & & \\
\hline 4 & 0 & 0 & 0 & 1 & & & & \\
\hline 5 & 2 & 0 & 0 & 0 & \multirow{2}{*}{0.160} & \multirow{2}{*}{48} & \multirow{6}{*}{2} & \multirow{6}{*}{155} \\
\hline 6 & 0 & 2 & 0 & 0 & & & & \\
\hline 7 & 1 & 0 & 1 & 0 & 0.181 & 4 & & \\
\hline 8 & 1 & 1 & 0 & 0 & \multirow{3}{*}{0.250} & \multirow{3}{*}{103} & & \\
\hline 9 & 0 & 1 & 0 & 1 & & & & \\
\hline 10 & 1 & 0 & 0 & 1 & & & & \\
\hline 11 & 1 & 0 & 2 & 0 & 0.347 & 1 & \multirow{11}{*}{3} & \multirow{11}{*}{80} \\
\hline 12 & 2 & 0 & 1 & 0 & \multirow{2}{*}{0.376} & \multirow{2}{*}{4} & & \\
\hline 13 & 0 & 2 & 1 & 0 & & & & \\
\hline 14 & 0 & 2 & 0 & 1 & \multirow{4}{*}{0.445} & \multirow{4}{*}{51} & & \\
\hline 15 & 2 & 1 & 0 & 0 & & & & \\
\hline 16 & 2 & 0 & 0 & 1 & & & & \\
\hline 17 & 1 & 2 & 0 & 0 & & & & \\
\hline 18 & 1 & 1 & 1 & 0 & \multirow{3}{*}{0.458} & \multirow{3}{*}{10} & & \\
\hline 19 & 1 & 0 & 1 & 1 & & & & \\
\hline 20 & 0 & 1 & 1 & 1 & & & & \\
\hline 21 & 1 & 1 & 0 & 1 & 0.563 & 14 & & \\
\hline
\end{tabular}


Table 2 (end)

\begin{tabular}{|c|c|c|c|c|c|c|c|c|}
\hline \multirow{2}{*}{$\begin{array}{c}\text { Combination } \\
\text { number }\end{array}$} & \multicolumn{4}{|c|}{ Work experience category* } & \multicolumn{2}{|c|}{ Diversity index } & \multicolumn{2}{|c|}{ Number of work experience types } \\
\hline & 1 & 2 & 3 & 4 & Value & Frequency & Value & Frequency \\
\hline 22 & 2 & 2 & 0 & 0 & 0.640 & 10 & \multirow{4}{*}{4} & \multirow{4}{*}{15} \\
\hline 23 & 2 & 1 & 0 & 1 & \multirow{2}{*}{0.855} & \multirow{2}{*}{4} & & \\
\hline 24 & 1 & 2 & 0 & 1 & & & & \\
\hline 25 & 1 & 1 & 1 & 1 & 0.861 & 1 & & \\
\hline 26 & 1 & 2 & 0 & 2 & 1.148 & 1 & \multirow{2}{*}{5} & \multirow{2}{*}{2} \\
\hline 27 & 1 & 1 & 2 & 1 & 1.194 & 1 & & \\
\hline 28 & 2 & 2 & 1 & 1 & 1.641 & 1 & 6 & 1 \\
\hline 29 & 2 & 2 & 3 & 2 & 2.560 & 1 & 9 & 1 \\
\hline
\end{tabular}

Notes: a work experience type is assigned a value of " 1 " if at least one director on the board has worked in the area in the past 10 years; * column reports the number of work experience types within the given category (for categories 1, 2 and 4 there could be 0.1 or 2 work experience types; for category 3 there could be 0.1 , 2 or 3 work experience types).

In more efficient companies, more stakeholders should contribute to a greater diversity of directors' experience. To take into account the number of influence groups on the composition of the board, three relative indicators of the diversity of experience were calculated: the ratio of the number of work experience types to the number of stakeholders, the ratio of the number of work experience categories and the diversity index to the number of stakeholders.

To assess the performance of companies, the return on shareholders' funds' ratio (ROSF) was used. Since we are considering industrial companies, the production of which is often capital-intensive, we additionally analyzed the company's return on capital employed (ROCE), which includes long-term liabilities. Based on the return on capital ratios, the deviations of the company's return on capital from the sector average for 2017 and 2019 were calculated. The sector average return on capital was calculated using data from 635 companies in the survey for each of 20 types of economic activity. Further, the change in the return on capital for two years was calculated as the difference between the values for 2019 and 2017.
Additionally, binary variables of the return on capital were created, reflecting the positive or negative change in the deviation from the average for the sector for two years: the variable takes on the value 1 if the company's return on capital relative to the average for the industry has increased over the period, and the value is 0 if the company's performance has worsened. Table 3 provides descriptive statistics of the dependent and independent variables.

\subsection{Methods and models}

To test hypothesis $\mathrm{H} 1$ that there are no prevailing work experience and its combinations, factor analysis was used. It detects the presence of unobservable factors that may lead to combinations of work experience. The factor analysis of the work experience types is based on approaches to the analysis of the personal characteristics of directors on boards and CEOs in [Kaplan, Klebanov, Sorensen, 2012; Kaplan, Sorensen, 2017; Adams, Akyol, Verwijmeren, 2018]. Following the work of [Adams, Akyol, Verwijmeren, 2018], the iterated principal axis method was used. 
Table 3

Variables descriptive statistics

\begin{tabular}{|c|c|c|c|c|c|c|c|}
\hline Variable & $\begin{array}{l}\text { Number } \\
\text { of } \\
\text { observa- } \\
\text { tions }\end{array}$ & Median & Mean & Minimum & Maximum & $\begin{array}{l}\text { Standard } \\
\text { deviation }\end{array}$ & Variable type \\
\hline \multicolumn{8}{|c|}{ Firm characteristics } \\
\hline $\begin{array}{l}\text { Change in the devia- } \\
\text { tion of ROSF from } \\
\text { the sector average } \\
\text { over } 2 \text { years, } \%\end{array}$ & 384 & 3.24 & -0.71 & -890.53 & 782.92 & 84.19 & Quantitative \\
\hline $\begin{array}{l}\text { Binary variable of the } \\
\text { change in the devia- } \\
\text { tion of ROSF from } \\
\text { the sector average } \\
\text { over } 2 \text { years }\end{array}$ & 384 & 1.00 & 0.56 & 0 & 1 & 0.50 & Dummy \\
\hline $\begin{array}{l}\text { Deviation of ROSF } \\
\text { from the sector } \\
\text { average in } 2017, \%\end{array}$ & 519 & -4.98 & 0.00 & -762.22 & 457.33 & 72.34 & Quantitative \\
\hline $\begin{array}{l}\text { Change in the devia- } \\
\text { tion of ROCE from } \\
\text { the sector average } \\
\text { over } 2 \text { years, } \%\end{array}$ & 413 & 5.64 & -2.17 & $\begin{array}{lll}-1 & 059.47\end{array}$ & 395.56 & 85.82 & Quantitative \\
\hline $\begin{array}{l}\text { Binary variable of the } \\
\text { change in the devia- } \\
\text { tion of ROCE from } \\
\text { the sector average } \\
\text { over } 2 \text { years }\end{array}$ & 413 & 1.00 & 0.61 & 0 & 1 & 0.49 & Dummy \\
\hline $\begin{array}{l}\text { Deviation of ROCE } \\
\text { from the sector } \\
\text { average in } 2017, \%\end{array}$ & 543 & -5.14 & 0.08 & -483.52 & 671.86 & 60.16 & Quantitative \\
\hline $\begin{array}{l}\text { Presence of foreign } \\
\text { ownership }\end{array}$ & 612 & 0 & 0.09 & 0 & 1 & 0.28 & Dummy \\
\hline $\begin{array}{l}\text { Management sepa- } \\
\text { rated from ownership }\end{array}$ & 620 & 1.00 & 0.61 & 0 & 1 & 0.49 & Dummy \\
\hline Number of markets & 632 & 1.00 & 1.50 & 1 & 3 & 0.71 & Quantitative \\
\hline $\begin{array}{l}\text { Foundation year }(1- \\
\text { before } 1992,2- \\
1992-1998,3- \\
1999-2008,4- \\
2009-2013, \\
5-2014-2018)\end{array}$ & 635 & 3 & 2.33 & 1 & 5 & 1.22 & Ordinal \\
\hline $\begin{array}{l}\text { Firm size (number of } \\
\text { employees in 2017) }\end{array}$ & 568 & 230.50 & 626.24 & 10 & 23916 & 1679.57 & Quantitative \\
\hline $\begin{array}{l}\text { Industries (9 groups), } \\
\text { including: }\end{array}$ & & & & & & & \\
\hline
\end{tabular}


Table 3 (end)

\begin{tabular}{|c|c|c|c|c|c|c|c|}
\hline Variable & $\begin{array}{l}\text { Number } \\
\text { of } \\
\text { observa- } \\
\text { tions }\end{array}$ & Median & Mean & Minimum & Maximum & $\begin{array}{l}\text { Standard } \\
\text { deviation }\end{array}$ & Variable type \\
\hline food & 635 & 0 & 0.17 & 0 & 1 & 0.38 & Dummy \\
\hline $\begin{array}{l}\text { textiles and gar- } \\
\text { ments }\end{array}$ & 635 & 0 & 0.06 & 0 & 1 & 0.24 & Dummy \\
\hline $\begin{array}{l}\text { timber and wood- } \\
\text { working }\end{array}$ & 635 & 0 & 0.08 & 0 & 1 & 0.27 & Dummy \\
\hline chemicals & 635 & 0 & 0.14 & 0 & 1 & 0.35 & Dummy \\
\hline $\begin{array}{l}\text { non-metallic } \\
\text { products }\end{array}$ & 635 & 0 & 0.10 & 0 & 1 & 0.31 & Dummy \\
\hline $\begin{array}{l}\text { metals and fabri- } \\
\text { cated metal products }\end{array}$ & 635 & 0 & 0.12 & 0 & 1 & 0.32 & Dummy \\
\hline $\begin{array}{l}\text { machines and } \\
\text { equipment }\end{array}$ & 635 & 0 & 0.10 & 0 & 1 & 0.29 & Dummy \\
\hline $\begin{array}{l}\text { electrical, electron- } \\
\text { ic, and optical } \\
\text { equipment }\end{array}$ & 635 & 0 & 0.11 & 0 & 1 & 0.32 & Dummy \\
\hline $\begin{array}{l}\text { transport vehicles } \\
\text { and equipment }\end{array}$ & 635 & 0 & 0.11 & 0 & 1 & 0.32 & Dummy \\
\hline \multicolumn{8}{|c|}{ BoD characteristics (in absolute values) } \\
\hline $\begin{array}{l}\text { Number of work } \\
\text { experience types }\end{array}$ & 602 & 1.00 & 1.63 & 1.00 & 9.00 & 0.90 & Quantitative \\
\hline $\begin{array}{l}\text { Number of work } \\
\text { experience categories }\end{array}$ & 602 & 1.00 & 1.40 & 1.00 & 4.00 & 0.61 & Quantitative \\
\hline Diversity index & 602 & 0.06 & 0.18 & 0.03 & 2.56 & 0.21 & Quantitative \\
\hline $\begin{array}{l}\text { Number of stakehold- } \\
\text { ers }\end{array}$ & 602 & 2.00 & 2.34 & 1.00 & 4.00 & 0.65 & Quantitative \\
\hline
\end{tabular}

N ot es: calculations were made for a sample of 635 companies, whose respondents noted the presence of a board of directors; at the same time, respondents who found it difficult or avoided answering on each question were excluded.

To test hypothesis $\mathrm{H} 2$, we assessed the change in the company's return on capital over two years in response to changes in one out of three relative indicators of the board experience diversity and several control variables: deviation of return on capital from the sector average in 2017 , firm size (logarithm of the number of employees in 2017), belonging to one of the nine manufacturing industries, foundation year (ordinal variable), presence of foreign owner- ship, separation of management from ownership, number of markets in which the company operates.

To test hypotheses about the relationship between the company's return on capital and the directors' experience diversity, two types of models were evaluated: a linear ordinary least squares (OLS) regression and a binary choice model (probit model).

A general regression equation is the following:

PЖM 19 (1): 5-34 (2021) 
Correlations table

\begin{tabular}{l|c|c|c}
\hline \multicolumn{1}{c|}{ Variable } & $\begin{array}{c}\text { Number of work experi- } \\
\text { ence types }\end{array}$ & $\begin{array}{c}\text { Number of work experi- } \\
\text { ence categories }\end{array}$ & Diversity index \\
\hline Number of stakeholders & $0.228 * * *$ & $0.184 * \% *$ & $0.219 \% * \%$ \\
\hline Number of areas & $0.206 * * *$ & $0.195 * * *$ & $0.213 \% * *$ \\
\hline Firm Size & $0.128 * * *$ & $0.080 * \%$ & $0.115 * * *$ \\
\hline
\end{tabular}

Not es: Spearman's correlation coefficient was used; $* * * * *$ indicate statistical significance at the 1 and $5 \%$ respectively.

Change in firm performance ${ }_{i}=$ $\beta_{0}+\beta_{1} W E D_{i}+\beta_{2}$ Return on capital $2017_{i}+$ $\beta_{3}$ Foreign $_{i}+\beta_{4}$ MnO $_{i}+\beta_{5}$ Nmarket $_{i}+\beta_{6}$ Size $_{i}+$ $\beta_{7}$ Year $_{i}+\beta_{8}$ Industry $_{i}+\beta_{i}$,

where Change in firm performance ${ }_{i}$ - the change in the deviation of ROSF (or ROCE) from the sector average from 2017 to 2019 for the company $i$; it can be expressed in absolute values or as a dummy (value 1 if the firm performance relative to the average for the industry has improved over the period, and the value is 0 if the firm performance has worsened or had the same dynamics as industry average); $W E D_{i}$ - a variable of the relative work experience diversity (the number of work experience types, or the number of categories, or the diversity index per stakeholder); Return on capital $2017_{i}$ - deviation of return on capital from the sector average in 2017; Foreign $_{i}$ dummy variable responsible for the presence of foreign ownership ${ }^{3} ; \mathrm{MnO}_{i}-$ dummy variable responsible for the separation of management from the ownership; Nmarkets N $_{i}$ the variable of the number of markets in which the company operates; Size $_{i}$ - a variable of the size of the company (logarithm of the number of employees in 2017); Year $_{i}$ - the foundation year; Industry I $_{i}$ a dummy variable showing which industry the $i$-th company belongs to; $\varepsilon_{i}$ - random error of the company $i$.

${ }^{3}$ Management is separate from the ownership when the CEO does not own shares of the company and he or she is not a member of the family that owns or controls the business; measured based on the subjective opinion of the respondent.

\section{RESULTS OF EMPIRICAL ANALYSIS}

\subsection{Factor analysis of work experience diversity}

During the preliminary testing the correlations of work experience diversity, the number of stakeholders influencing the formation of the board of directors, the number of areas that the BoD influences, and the size of the company were calculated. If the data on the experience of the councils is informative, a positive relationship between the variables should be found: large companies are faced with a large number of issues that need to be addressed, which means that the board should have more competencies; a large number of stakeholders should lead to a greater number of directors representing the interests of individual groups, and therefore to a greater number of work experiences in the board; a high variety of BoD competencies allows solving a larger number of tasks.

The correlation table showed a positive relationship between the variables, the work experience revealed in the survey is informative (Table 4). It is impossible to accept the null hypothesis of no correlation between the variables.

Next, the links between different work experiences in the BoD were analyzed. The tetrachoric correlation matrix of nine different types of work experience (see Table 5) shows little correlation between different 
Tetrachoric correlations of work experience types

\begin{tabular}{c|l|c|c|c|c|c|c|c|c|c}
\hline $\mathbf{N}$ & \multicolumn{1}{|c|}{ Type } & $\mathbf{1}$ & $\mathbf{2}$ & $\mathbf{3}$ & $\mathbf{4}$ & $\mathbf{5}$ & $\mathbf{6}$ & $\mathbf{7}$ & $\mathbf{8}$ & $\mathbf{9}$ \\
\hline 1 & In the company & 1.00 & & & & & & & & \\
\hline 2 & $\begin{array}{l}\text { In the group of related } \\
\text { companies }\end{array}$ & -0.32 & 1.00 & & & & & & & \\
\hline 3 & $\begin{array}{l}\text { In other companies in the } \\
\text { industry }\end{array}$ & -0.29 & 0.17 & 1.00 & & & & & & \\
\hline 4 & In other industries & -0.20 & 0.02 & 0.32 & 1.00 & & & & & \\
\hline 5 & In federal authorities & -0.18 & 0.11 & -0.10 & 0.36 & 1.00 & & & & \\
\hline 6 & $\begin{array}{l}\text { In regional / municipal } \\
\text { authorities }\end{array}$ & -0.26 & 0.02 & 0.00 & 0.19 & 0.56 & 1.00 & & & \\
\hline 7 & In the law enforcement agencies & -0.12 & 0.49 & 0.41 & 0.36 & 0.50 & 0.49 & 1.00 & & \\
\hline 8 & $\begin{array}{l}\text { In entrepreneurship or other } \\
\text { business management }\end{array}$ & -0.50 & 0.02 & 0.14 & 0.37 & 0.46 & 0.16 & 0.49 & 1.00 & \\
\hline 9 & $\begin{array}{l}\text { In social, political, scientific } \\
\text { and educational activities }\end{array}$ & -0.12 & 0.06 & 0.33 & 0.28 & 0.35 & 0.35 & 0.59 & 0.30 & 1.00 \\
\hline
\end{tabular}

types of work experience, apart from work experience in government.

Since in the overwhelming majority of companies there are directors with experience in the company (top management representatives) in the BoD, 8 types of experience were left for factor analysis: experience in the group of related companies, in other companies in the industry, in other industries, in the government authorities (3 types), managerial experience and experience in social, political, scientific and educational activities.

Three methods were used to determine the required number of factors: a scree plot analysis, parallel analysis, and eigenvalues analysis using the Kaiser-Harris test.

According to the scree plot, only the factors before the point inflexion should be used, which in this case corresponds to one factor. The second criterion, parallel analysis, offers some factors for which the eigenvalues calculated from real data are larger than the averaged eigenvalues for a set of random data matrices (FA simulated data). According to the second criterion, four factors should be taken.
According to the Kaiser-Harris rule, one should use only those factors whose eigenvalues are greater than zero, which corresponds to the use of four factors (see Figure).

The preliminary analysis gave mixed results, so two sets of factors were used. Table 6 shows the results of the iterated principal axis analysis for four and one factors. Taking into account four factors gives a low communality of all initial variables, and the proportion of cumulative variance explained by the factors is $65 \%$. Each variable of work experience is positively correlated with the first factor, the ratio ranges from 32 to $94 \%$. The eigenvalue of the first factor is almost three times higher than the next, which indicates its higher load compared to the rest. Using one factor gives similar results. It is positively correlated with all types of work experience - the influence ranges from 26 to $96 \%$, but it explains only $33 \%$ of the variance. This suggests that some boards have a large number of different types of work, while others, on the contrary, have a small variety of experience. 


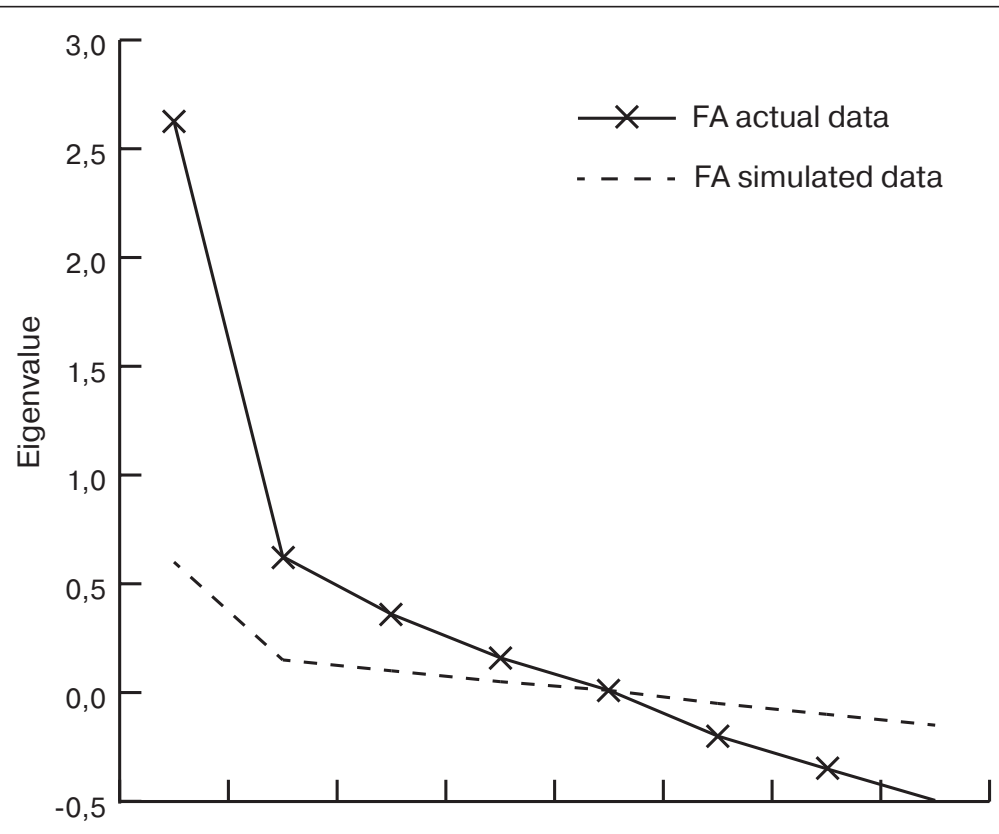

Factor number

Figure. Scree plot with parallel analysis

Table 6

Results of factor analysis

\begin{tabular}{|c|c|c|c|c|c|c|c|c|c|}
\hline \multirow{2}{*}{ Work experience type } & \multicolumn{6}{|c|}{ Four factors } & \multicolumn{3}{|c|}{ One factor } \\
\hline & $F 1$ & $F 2$ & F3 & $F 4$ & $h 2$ & $u 2$ & $F 1$ & $h 2$ & $u 2$ \\
\hline $\begin{array}{l}\text { In the group of related } \\
\text { companies }\end{array}$ & 0.32 & 0.45 & -0.64 & 0.13 & 0.74 & 0.26 & 0.26 & 0.066 & 0.934 \\
\hline $\begin{array}{l}\text { In other companies in the } \\
\text { industry }\end{array}$ & 0.39 & 0.66 & 0.38 & -0.21 & 0.77 & 0.23 & 0.32 & 0.101 & 0.899 \\
\hline In other industries & 0.47 & 0.02 & 0.26 & 0.10 & 0.30 & 0.70 & 0.48 & 0.227 & 0.773 \\
\hline $\begin{array}{l}\text { In federal legislative or } \\
\text { executive authorities }\end{array}$ & 0.66 & -0.45 & -0.08 & 0.13 & 0.67 & 0.33 & 0.62 & 0.388 & 0.612 \\
\hline $\begin{array}{l}\text { In regional / municipal } \\
\text { executive or legislative } \\
\text { authorities }\end{array}$ & 0.59 & -0.44 & -0.13 & -0.44 & 0.76 & 0.24 & 0.52 & 0.266 & 0.734 \\
\hline $\begin{array}{l}\text { In the law enforcement, } \\
\text { military or security } \\
\text { agencies }\end{array}$ & 0.94 & 0.21 & -0.17 & -0.01 & 0.96 & 0.04 & 0.96 & 0.915 & 0.085 \\
\hline $\begin{array}{l}\text { In entrepreneurship or } \\
\text { management of other } \\
\text { companies }\end{array}$ & 0.58 & -0.12 & 0.25 & 0.45 & 0.61 & 0.39 & 0.54 & 0.288 & 0.712 \\
\hline
\end{tabular}


Table 6 (end)

\begin{tabular}{|c|c|c|c|c|c|c|c|c|c|}
\hline $\begin{array}{l}\text { In activities that are socio- } \\
\text { political, scientific, } \\
\text { educational }\end{array}$ & 0.60 & 0.04 & 0.15 & -0.14 & 0.40 & 0.60 & 0.61 & 0.378 & 0.622 \\
\hline Eigenvalue* & 2.84 & 1.09 & 0.77 & 0.51 & & & 2.63 & & \\
\hline $\begin{array}{l}\text { Percentage of variance } \\
\text { explained } * *\end{array}$ & 0.35 & 0.14 & 0.10 & 0.06 & & & 0.33 & & \\
\hline $\begin{array}{l}\text { Cumulative percentage of } \\
\text { variance explained }\end{array}$ & 0.35 & 0.49 & 0.59 & 0.65 & & & 0.33 & & \\
\hline
\end{tabular}

N o t es: F1, F2, F3 and F3 represent unrotated factor loadings using the principal axis method; $h 2-$ measure of variable communality; $u 2$ - measure of variable uniqueness; *eigenvalue and **the percentage of variance explained are represented for each factor.

The Kaiser-Meyer-Olkin (KMO) test was also carried out, the KMO coefficient was $61 \%$, which indicates the applicability of factor analysis. However, the value is small and indicates a "mediocre" intercorrelation relationship. Thus, we cannot talk about the existence of unobservable factors that lead to the presence of any combination of director experience. Boards of directors of companies differ in the degree of diversity of their experience.

\subsection{BoD work experience diversity and company's performance}

The influence of relative work experience diversity on the change in the deviation of return on capital from the sector average from 2017 to 2019 is shown in Table 7.

All OLS specifications of the model are significant and show a high coefficient of determination - from 42 to $44 \%{ }^{4}$. An increase in the relative diversity index leads to an increase in the ROSF relative to the sector average from 2017 to 2019 . The influence of the base deviation of the ROSF in 2017 has a negative influence on the change over two years: the higher is its initial level, the lower the growth of the ROSF from 2017 to 2019. That is, it is more difficult for more efficient companies to maintain development at the same level due to di-

\footnotetext{
4 The test for multicollinearity of variables (VIF) showed that the variance inflation factors are small, there is no multicollinearity (Appendix, Table 1).
}

minishing returns on investment. The presence of foreign ownership in non-public companies negatively affects the change in the return on equity, the difference is about $50 \%$ compared to companies without foreign owners. This can be explained by the negative role of sanctions of 2014. The work diversity positively affects the company's performance in the case of combining management and ownership functions, and the separation of functions reduces the growth of return on equity by $13-15 \%$. Coefficients for the control variables of size, age, and industry were found to be insignificant. The absence of the influence of industry affiliation can be explained by the fact that the dependent variable is calculated as the deviation of the return on capital from the sector average, that is, its specific was taken into account initially. It is also possible that standard errors of a given variable are too large and obscure the effect [Fahlenbrach, Low, Stulz, 2010].

Specifications with the relative number of experience types or categories showed similar results, which indicates their sustainability (Appendix, Table 2). Similarly, the impact of the work diversity on the ROCE was tested. The results were almost identical ${ }^{5}$.

To further check the robustness of the results, the dependence of the binary variable of the change in the deviation of the ROSF relative to the sector average from 2017 to 2019 was assessed. The results are presented in Table 8.

\footnotetext{
5 The results can be submitted by the authors upon request.
} 
The impact of the work experience diversity index on the change in the ROSF, 2017-2019

\begin{tabular}{|c|c|c|c|c|c|c|}
\hline \multirow{2}{*}{ Variable $\quad$ Model } & \multicolumn{6}{|c|}{ OLS } \\
\hline & M1 & M2 & M3 & M4 & M5 & M6 \\
\hline Constant term & -5.445 & -2.307 & -6.905 & -1.550 & -10.246 & -9.368 \\
\hline Diversity index & $82.072 * \% *$ & $97.333 * * *$ & $95.321 * * *$ & $99.585 * * *$ & $96.998 * * *$ & $101.243 * * *$ \\
\hline $\begin{array}{l}\text { Deviation of ROSF } \\
\text { from the sector } \\
\text { average in } 2017\end{array}$ & $-0.748 * * *$ & $-0.762 * * *$ & $-0.762 * * *$ & $-0.760 * * *$ & $-0.764 * * *$ & $-0.765 * * *$ \\
\hline $\begin{array}{l}\text { Presence of foreign } \\
\text { ownership }\end{array}$ & $-48.978 * * *$ & $-46.244 * * *$ & $-46.351 * * *$ & $-46.406 * * *$ & $-48.928 * * *$ & $-49.082 * * *$ \\
\hline $\begin{array}{l}\text { Management separated } \\
\text { from ownership }\end{array}$ & & $-15.185 * *$ & $-15.143 * *$ & $-14.712 *$ & $-13.592 *$ & $-14.807 *$ \\
\hline Number of markets & & & 3.271 & 3.920 & 4.818 & 5.439 \\
\hline Firm size & & & & -1.350 & -0.686 & -1.413 \\
\hline Foundation year & & & & & Yes & Yes \\
\hline Industry & & & & & & Yes \\
\hline Number of observations & 373 & 361 & 361 & 358 & 358 & 358 \\
\hline $\mathrm{R}^{2}$ & 0.421 & 0.430 & 0.432 & 0.431 & 0.432 & 0.440 \\
\hline Significance of the model & 0.000 & 0.000 & 0.000 & 0.000 & 0.000 & 0.000 \\
\hline
\end{tabular}

Notes: $* * * * *, *$ indicate statistical significance at the 1,5 and $10 \%$ respectively; variables which are not used in the regression are set to blank.

Table 8

The impact of the work experience diversity index on probability of ROSF increase, 2017-2019

\begin{tabular}{|c|c|c|c|c|c|c|}
\hline \multirow{2}{*}{ Variable } & \multicolumn{6}{|c|}{ Probit } \\
\hline & M7 & M8 & M9 & M10 & M11 & M12 \\
\hline Constant term & + & + & + & + & + & + \\
\hline Diversity index & $+*$ & $+* *$ & $+* *$ & $+* *$ & $+* *$ & $+* *$ \\
\hline $\begin{array}{l}\text { Deviation of ROSF from } \\
\text { the sector average in } \\
2017\end{array}$ & $-* * *$ & $-* * *$ & $-* * *$ & $-* * *$ & $-* * *$ & $-* * *$ \\
\hline $\begin{array}{l}\text { Presence of foreign } \\
\text { ownership }\end{array}$ & - & - & - & - & - & - \\
\hline $\begin{array}{l}\text { Management separated } \\
\text { from ownership }\end{array}$ & & - & - & - & - & - \\
\hline Number of markets & & & - & - & - & - \\
\hline Firm size & & & & - & - & - \\
\hline Foundation year & & & & & Yes & Yes \\
\hline
\end{tabular}


Table 8 (end)

\begin{tabular}{|c|c|c|c|c|c|c|}
\hline \multirow{2}{*}{ Variable $\quad$ Model } & \multicolumn{6}{|c|}{ Probit } \\
\hline & M7 & M8 & M9 & M10 & M11 & M12 \\
\hline Industry & & & & & & Yes $* * *$ \\
\hline Number of observations & 373 & 361 & 361 & 358 & 358 & 358 \\
\hline Log likelihood & -217 & -210 & -210 & -208 & -207 & -186 \\
\hline Pseudo $\mathrm{R}^{2}$ (McFadden) & 0.176 & 0.202 & 0.204 & 0.210 & 0.215 & 0.293 \\
\hline $\begin{array}{l}\text { Percent correctly pre- } \\
\text { dicted, } \%\end{array}$ & 71.6 & 72.0 & 72.0 & 72.3 & 72.9 & 76.3 \\
\hline
\end{tabular}

N ot es: only signs of the coefficients are given: the “+” sign means a positive relationship, the "-” sign - a negative; $* * *, * * *$ indicate statistical significance at the 1,5 and $10 \%$ respectively; variables which are not used in the regression are set to blank; coefficients of control dummy variables of foundation year and industry are not presented for brevity; "Yes" is written if used.

In all specifications, a significant effect was found for the relative diversity index. At the $10 \%$ significance level in the M7 model with a few independent variables and the $5 \%$ significance level in the M8-M12 specifications. An increase in the work experience diversity index increases the likelihood of an improvement in a company's ROSF. In all specifications, the deviation of return on capital from the sector average in 2017 negatively affects the likelihood of performance improvement, this is the effect of the "high base". Foreign ownership variables, separation of management from ownership, and the number of markets do not affect the likelihood of performance improvement, nor do control variables of size and foundation year. In binary models, the industry of the business turned out to be significant at 1\% level for three sectors - the forestry and woodworking industry, the production of non-metallic products, and electrical and electronic engineering. Note a fairly high percentage of correct predictions of models - up to $76 \%{ }^{6}$. Specifications with alternative measures of

\footnotetext{
${ }^{6}$ For the convenience of interpreting binary probit models, the marginal effects of the M7-M12 specifications were evaluated (Appendix, Table 3).
}

diversity showed similar results (Appendix, Table 2).

To test the robustness of the results, models with an alternative indicator ROCE were tested. In the final specification M12, the diversity index is significant at $10 \%$ level and with a positive coefficient. Similar to the analysis of the change in ROSF deviation, there is an effect of the high base - the performance indicator for 2017 negatively and significantly affects the likelihood of ROCE improving. At the same time, the M12 model showed the influence of the foundation year and industry.

We emphasize that for additional verification of the robustness of the results for all specifications above, other values of the coefficient $\mathrm{k}$ were used for the calculation of the work experience diversity index (including the coefficients 0.7 and 0.9 ), the results do not differ significantly.

In general, the work experience diversity has a positive influence on the return on capital of companies, the coefficient of the diversity index is significant for all given specifications, which indicates the reliability of the results. For OLS specifications, the coefficients of alternative work experience diversity indicators also turned out to be significant; for binary models, these indicators were signifi-

PЖM 19 (1): 5-34 (2021) 
cant when the control variables were included. In addition to the indicator of the work experience diversity, the the improvement of the company's performance is influenced by the initial position of the company — it is easier for companies with operating results below the industry average in 2017 to improve results in two years, compared to companies that were more successful initially. The use of an alternative indicator of the company's performance gave similar results, which confirms their robustness.

\section{CONCLUSION}

The modern literature shows mixed results on the influence of different work experiences of the board on the performance of companies. The majority of papers considered the role of one or another type of experience. In this paper on Russian non-public industrial companies, for the first time, the work experience diversity was analyzed, considering the collective experience of the board. To measure the experience diversity, three indicators were taken: the number of work experience types (there were nine), the number of work experience aggregated categories (four categories), and the diversity index proposed by the authors. The diversity index is a more detailed indicator that takes into account the "saturation" of each category, that is, the share of experience presented in that category. In this case, the diversity index by construction takes into account the "bias" towards any work experience category. The particular strength of the data should be mentioned - the data was taken from the survey and represents the firms' topmanagement perspective.

Factor analysis has shown that there are no prevailing combinations of work experience inherent in Russian industrial companies. The hypothesis $\mathrm{H} 1$ was thus confirmed.

Next, the relationship between company performance and work experience diversity was assessed. Since the data from non-public companies was used, the company's return on capital (an indicator that was calculated based on financial statements) was taken as a variable of company's performance, rather than the market value. The directors' work experience diversity was measured by one of three relative indicators: the ratio of the number of work experience types to the number of stakeholders, the ratio of the number of work experience categories and the diversity index to the number of stakeholders. The main task of corporate governance is to prevent conflicts between all stakeholders, to find compromises between their interests, so directors should have different skills and work experience. In other words, in successful companies, a greater variety of work experiences must correspond to a larger number of stakeholders, or relative work experience diversity should be higher.

A significant positive effect of the BoD work experience diversity on the return on capital was found. This result was noted for most specifications using alternative dependent variables and measures of diversity, as well as two methods of regression analysis. This indicates the robustness of the results obtained and confirms the hypothesis H2. The main task of the councils is to take into account the interests of all stakeholders and find compromise solutions. The more different stakeholders a company has, the more tasks the board of directors can face, and the more directors' competencies are required for better business performance. The impact of the work experience diversity on changes in the company's performance from 2017 to 2019 was assessed, while the data on the board work experience was collected for 2017. Therefore, the problem of endogeneity in terms of the inverse relationship between the work experience diversity and the company's performance was mostly eliminated.

Obtained results are in line with research where the positive effect of the increased variety of directors' qualities on the value of the company was shown [Anderson et al., 2011] and the importance of the combined effect of the directors' diversity was noted [Bernile, Bhagwat, Yonker, 2018]. At the same time current results are contrary to 
results of A. Knyazeva with coauthors and R. Adams with coauthors who showed that greater diversity leads to the lack of focus and consensus on boards [Knyazeva, Knyazeva, Raheja, 2013; Adams, Akyol, Verwijmeren, 2018]. However, it should be noted that aforementioned works are based on the data of publicly traded companies in developed countries, while the current research was focused on the impact of the board of directors' work experience diversity on the performance of Russian non-public companies. Regarding literature on Russian companies in general, the study confirms the resource role of the board of directors played in companies in terms of positive effects of director work experience in the company and in the industry [Dulyak, 2015] and in terms of positive influence of director past experience in the BoD of the other companies [Berezinets, Ilina, Loginova, 2019] on the firm performance.

This research showed the importance of the board work experience diversity and shed the light on the role of BoD in non-public companies. The actual board performance may depend on the tasks faced by companies, which in turn relate to firm performance and director qualities and skills. Future research could examine

\section{REFERENCES}

Adams R. B., Akyol A. C., Verwijmeren P. 2018. Director skill sets. Journal of Financial Economics 130 (3): 641-662.

Adams R. B., Ferreira D. 2007. A theory of friendly boards. The Journal of Finance $\mathbf{6 2}$ (1): 217-250.

Adams R. B., Ferreira D. 2009. Women in the boardroom and their impact on governance and performance. Journal of Financial Economics 94 (2): 291-309.

Agrawal A., Knoeber C. R. 2001. Do some outside directors play a political role? Journal of Law and Economics 44 (1): 179-198. the link between tasks, firm performance and the diversity of the BoD.

\section{ACKNOWLEDGMENTS}

The authors are grateful to the employees of GFK-Rus for surveying a representative sample of companies, which was funded by the HSE Basic Research Program. We are also grateful to all respondents for the time they spent completing the extensive questionnaires. The first results of the research were reported at the 43rd International Scientific School-Seminar named after academician S. S. Shatalin "Systemic modeling of socio-economic processes" (Voronezh, October 2020), IV Russian Economic Congress (Moscow, December 2020), and 7 GSOM Emerging Markets Conference (St. Petersburg, November 2020). We are grateful to all the participants of these (online) events for their comments and observations and especially grateful to the anonymous referee for comments and remarks, however, the responsibility for the interpretation of the results and conclusions from the study lies solely on the authors.

Anderson R. C., Reeb D. M., Upadhyay A., Zhao W. 2011. The economics of director heterogeneity. Financial Management $\mathbf{4 0}$ (1): 5-38.

Bankewitz M. 2016. Boards' different advisory tasks - what makes board members use their knowledge? American Journal of Management 16 (1): 54-69.

Berezinets I. V., Ilina Yu. B., Cherkasskaya A. D. 2013. Board structure and financial performance of Russian public companies. Vestnik S.-Peterburgskogo Universiteta. Seriya Menedzhment (2): 3-52. (In Russian)

PЖM 19 (1): 5-34 (2021) 
Berezinets I., Ilina Yu., Loginova A. 2019. Effects of board social capital on corporate performance: Evidence from Russia. Contributions to Game Theory and Management 12: 49-69.

Bernile G., Bhagwat V., Yonker S. 2018. Board diversity, firm risk, and corporate policies. Journal of Financial Economics 127 (3): 588-612.

Brickley J. A., Zimmerman J. L. 2010. Corporate governance myths: Comments on Armstrong, Guay, and Weber. Journal of Accounting and Economics 50 (2-3): 235245.

Cavaco S., Crifo P., Rebérioux A., Roudaut G. 2017. Independent directors: Less informed but better selected than affiliated board members? Journal of Corporate Finance 43 (C): 106-121.

Cruz C., Justo R., Larraza-Kintana M., Garcés-Galdeano L. 2019. When do women make a better table? Examining the influence of women directors on family firm's corporate social performance. Entrepreneurship Theory and Practice 43 (2): 282301.

Dass N., Kini O., Nanda V., Onal B., Wang J. 2014. Board expertise: do directors from related industries help bridge the information gap? The Review of Financial Studies 27 (5): 1533-1592.

Davis J. H., Schoorman F. D., Donaldson L. 1997. Toward a stewardship theory of management. Academy of Management Review 22 (1): 20-47.

DiMaggio P. J., Powell W. W. 1983. The iron cage revisited: Institutional isomorphism and collective rationality in organizational fields. American Sociological Review 48 (2): $147-160$.

Dolgopyatova T. G. 2011. Hired managers in Russian firms: Empirical evidence at the time of crisis. Finance and Business 4: 149-165. (In Russian)

Dolgopyatova T. G., Libman A. M., Petrov I. O., Yakovlev A. A. 2015a. The role of a board of directors in Russian growing companies: A case of joint stock financial corporation "Sistema", Part I. Rus - sian Management Journal 13 (1): 91112. (In Russian)

Dolgopyatova T. G., Libman A. M., Petrov I. O., Yakovlev A. A. 2015b. The role of a board of directors in Russian growing companies: A case of joint stock financial corporation "Sistema", part II. Russian Management Journal 13 (2): 129148. (In Russian)

Drobetz W., Von Meyerinck F., Oesch D., Schmid M. 2017. Industry expert directors. Unpublished working paper, University of St. Gallen. Available at: https://papers. ssrn.com/sol3/papers.cfm?abstract_ $\mathrm{id}=2256477$ (accessed: 09.11.2020).

Dulyak Yu. I. 2015. Empirical analysis of the boards of directors' impact on the corporate performance of Russian companies. Ekonomicheskaya Politika 10 (1): 126148. (In Russian)

Fahlenbrach R., Low A., Stulz R. M. 2010. Why do firms appoint CEOs as outside directors? Journal of Financial Economics 97 (1): 12-32.

Fich E. M. 2005. Are some outside directors better than others? Evidence from director appointments by Fortune 1000 firms. The Journal of Business 78 (5): 1943-1971.

Garanina T. A., Muravyev A. A. 2018. Boards of directors in Russian publicly traded companies: The gender aspect. Voprosy Ekonomiki (2): 142-155. (In Russian)

Garlappi L., Giammarino R., Lazrak A. 2017. Ambiguity and the corporation: Group disagreement and underinvestment. Journal of Financial Economics 125 (3): 417-433.

Goldman E., Rocholl J., So J. 2009. Do politically connected boards affect firm value? The Review of Financial Studies 22 (6): 2331-2360.

Granovetter M. 1985. Economic action and social structure: The problem of embeddedness. American Journal of Sociology 91 (3): $481-510$.

Güner A. B., Malmendier U., Tate G. 2008. Financial expertise of directors. Journal of Financial Economics 88 (2): 323-354.

Hambrick D. C., Cho T. S., Chen M. J. 1996. The influence of top management team het- 
erogeneity on firms' competitive moves. Administrative Science Quarterly 41 (4): 659-684.

Hauser R. 2018. Busy directors and firm performance: Evidence from mergers. Journal of Financial Economics 128 (1): 1637.

Hermalin B. E., Weisbach M. S. 2003. Boards of directors as an endogenously determined institution: A survey of the economic literature. Federal Reserve Bank of New York Economic Policy Review 9 (1): 7-26.

Jensen M. C., Meckling W. H. 1976. Theory of the firm: Managerial behaviour, agency costs and ownership structure. Journal of Financial Economics 3 (4): 305-360.

Kang S., Kim E. H., Lu Y. 2018. Does independent directors' CEO experience matter? Review of Finance 22 (3): 905-949.

Kaplan S. N., Klebanov M. M., Sorensen M. 2012. Which CEO characteristics and abilities matter? The Journal of Finance 67 (3): 973-1007.

Kaplan S. N., Sorensen M. M. 2017. Are CEOs Different? Characteristics of Top Managers. NBER Working paper No. 23831. Available at: https://www.nber.org/papers/w23832 (accessed: 09.11.2020).

Knight D., Pearce C. L., Smith K. G., Olian J. D., Smith H. P., Flood P. 1999. Top management team diversity, group process, and strategic consensus. Strategic Management Journal 20 (5): 445-465.

Knyazeva A., Knyazeva D., Raheja C. 2013. The Benefits of Focus vs. Heterogeneity: Dissimilar Directors and Coordination within Corporate Boards. Unpublished working paper, University of Rochester. Available at: https://papers.ssrn.com/ sol3/papers.cfm?abstract_id $=2083287$ (accessed: 09.11.2020).

Lee J., Lee K. L., Nagarajan N. J. 2014. Birds of a feather: Value implications of political alignment between top management and directors. Journal of Financial Economics 112 (2): 232-250.

Linck J. S., Nettera J. M., Yang T. 2008. The determinants of board structure. Journal of Financial Economics 87 (2): 308-328
Milliken F. J., Martins L. L. 1996. Searching for common threads: Understanding the multiple effects of diversity in organizational groups. Academy of Management Review 21 (2): 402-433.

Minton B. A., Taillard J. P., Williamson R. 2014. Financial expertise of the board, risk taking, and performance: Evidence from bank holding companies. Journal of Financial and Quantitative Analysis 49 (2): 351-380.

Muravyev A., Berezinets I., Ilina Y. 2014. The structure of corporate boards and private benefits of control: Evidence from the Russian stock exchange. International Review of Financial Analysis 34: 247261.

Muravyev A. 2017. Boards of directors in Russian publicly traded companies in 1998-2014: Structure, dynamics and performance effects. Economic Systems $\mathbf{4 1}$ (5): $5-25$.

Murray A. I. 1989. Top management group heterogeneity and firm performance. Strategic Management Journal 10 (Special Issue, Summer): 125-141.

Pelled L. H., Eisenhardt K. M., Xin K. R. 1999. Exploring the black box: an analysis of work group diversity, conflict, and performance. Administrative Science Quarterly 44 (1): 1-28.

Pfeffer J., Salancik G. R. 1978. The External Control of Organizations: A Resource Dependence Approach. Harper \& Row Publishers: N.Y.

Research of corporate governance practices: Evidence of Russian medium-sized and nonpublic companies. 2020. Russian Institute of Directors. [Electronic resource]. http:// rid.ru/wp-content/uploads/2020/05/RID_ ISSLED_2020_web_итог.pdf (accessed: 12.02.2021). (In Russian)

The New Economic School, PricewaterhouseCoopers in Russia, PwC Technology and Innovation Center. 2010. Innovation activity of large business in Russia: Mechanisms, drivers, perspectives. Russian Management Journal 8 (4): 81-112. (In Russian)

PЖM 19 (1): 5-34 (2021) 
Zahra S. A., Pearce J. A. 1989. Boards of directors and corporate financial performance: A review and integrative model. Journal of Management 15 (2): 291-334.

Zhu J., Ye K., Tucker J. W., Chan K. C. 2016. Board hierarchy, independent direc- tors, and firm value: Evidence from China. Journal of Corporate Finance 41: $262-279$.

Zingales L. 2000. In search of new foundations. The Journal of Finance 55 (4): 1623-1653.

Initial Submission: March 2, 2021

Final Version Accepted: March 31, 2021

Разнообразие опьта работьи членов советов директоров российских колпаний и эффективность бизнеса

\section{И. В. Дергунова, Т. Г. Долгопятова}

Институт анализа предприятий и рынков, Национальный исследовательский университет «Высшая школа экономики», Россия

Цель исследования - эмпирически оценить влияние разнообразия опыта работы членов советов директоров на эффективность непубличных российских компаний. В качестве показателей разнообразия используется предложенный авторами индекс разнообразия, а также количество видов и количество категорий опыта работы у членов совета. Российским советам не присуще высокое разнообразие, преобладают директора с опытом работы на данном предприятии, на втором и третьем месте отмечены опыт работы на других предприятиях данной отрасли и в своей группе компаний. Установлено, что не существует превалирующих комбинаций опыта работы в промышленных компаниях. Обнаружено положительное влияние разнообразия опыта работы директоров на рост рентабельности капитала компаний в период с 2017 по 2019 г. Анализ базируется на данных опроса руководителей промышленных предприятий, проведенного НИУ ВШЭ в 2018 г.

Ключевые слова: разнообразие опыта, эффективность компании, корпоративное управление, совет директоров.

JEL: G32, G34, M14.

For citation: Dergunova I. V., Dolgopyatova T. G. 2021. The board work experience diversity and the performance of Russian companies. Russian Management Journal 19 (1): 5-34.

Статья поступила в редакцию

2 мларта 2021 г.

Принята к публикации

31 мая 2021 г.

PЖM 19 (1): 5-34 (2021) 


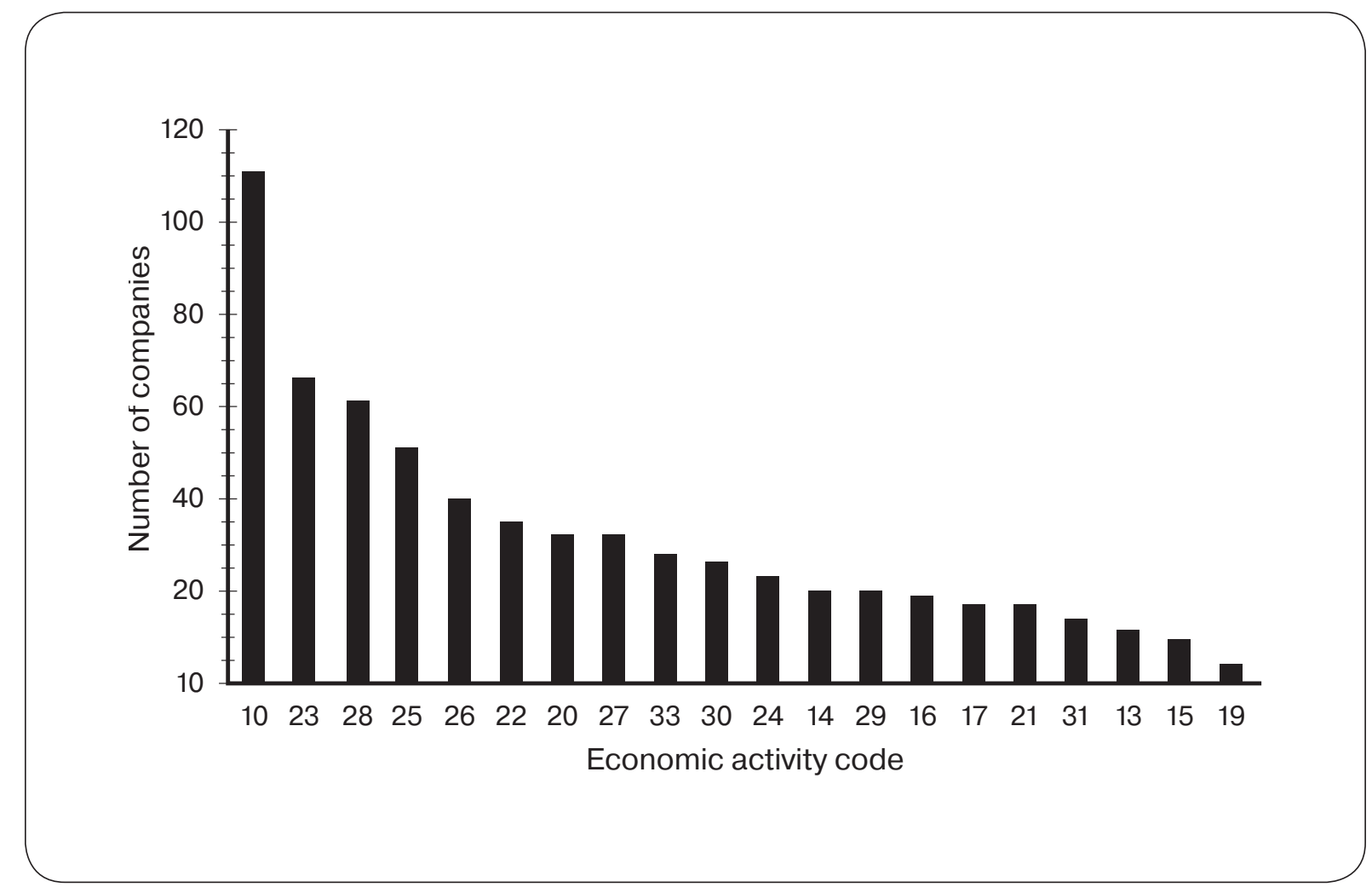

Fig. 1. Distribution of Russian companies by 20 types of economic activities

B a s ed on: database of the survey of manufacturing enterprises top management conducted by the IIMS of the NRU HSE; the description of economic activity codes is taken from Federal State Statistics Service website. URL: https://rosstat.gov.ru/classification.

Notes: 10 - Food production, 23 - Textile production, 28 - Production of clothes, 25 Production of leather, leather goods, shoes, 26 - Wood processing and manufacture of wood and cork, except furniture, manufacture of straw and weaving materials , 22 - Manufacture of pulp, paper, cardboard and products from them, 20 - Manufacture of coke and oil products, 27 Chemical production, 33 - Production of medicines and materials used for medical purposes, 30 - Rubber and plastic products manufacture, 24 - Manufacture of other non-metallic mineral products, 14 - Metallurgical manufacture, 29 - Manufacture of finished metal products, except for machinery and equipment production, 16 - Manufacture of computers, electronics and optical equipment, 17 - Production of electronic machines and equipment, 21 - Manufacture of machinery and equipment not included in other groups, 31 - Manufacture of motor vehicles, trailers and semi-trailers, 13 - Manufacture of other vehicles and equipment, 15 - Furniture production, 19 - Repair and installation of machinery and equipment. 


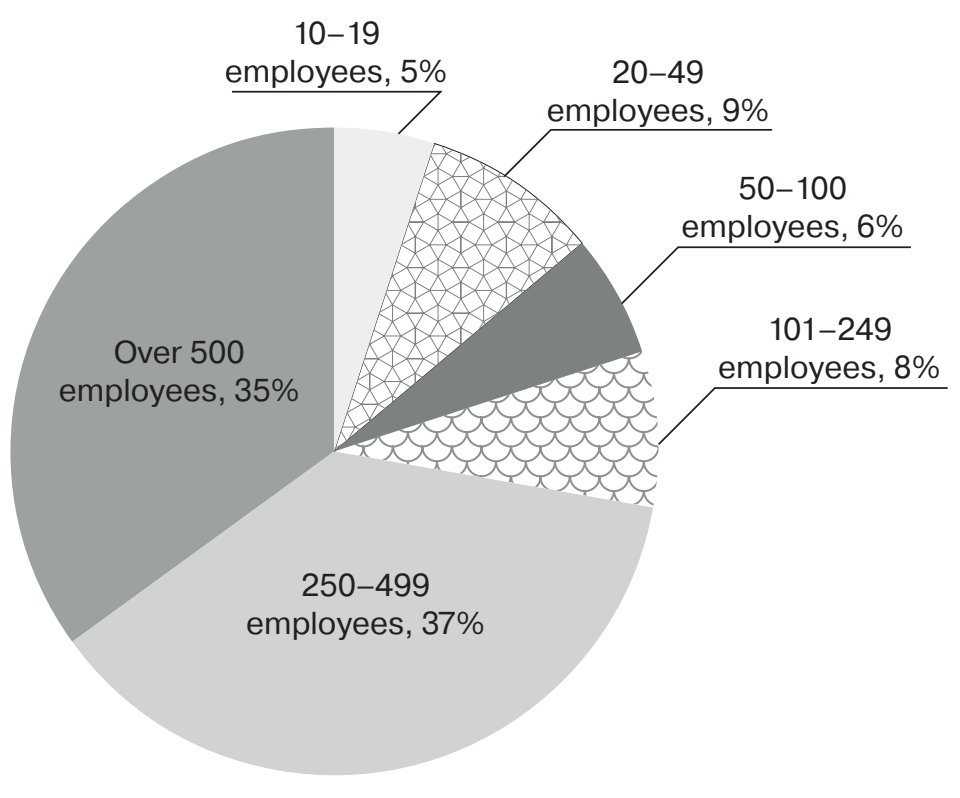

Fig. 2. Distribution of Russian companies by size (number of employees)

B as ed on: database of the survey of manufacturing enterprises top management conducted by the IIMS of the NRU HSE; the description of economic activity codes is taken from Federal State Statistics Service website. URL: https://rosstat.gov.ru/classification (accessed: 09.11.2020).

Variance inflation factor estimation for OLS models

Table 1

\begin{tabular}{|c|c|c|c|c|c|c|}
\hline \multirow{2}{*}{ Variable } & \multicolumn{6}{|c|}{ Model } \\
\hline & M1 & M2 & M3 & M4 & M5 & M6 \\
\hline Diversity index & 1.01 & 1.05 & 1.05 & 1.06 & 1.07 & 1.12 \\
\hline $\begin{array}{l}\text { Deviation of ROSF from } \\
\text { the sector average in } \\
2017\end{array}$ & 1.01 & 1.01 & 1.01 & 1.01 & 1.03 & 1.03 \\
\hline $\begin{array}{l}\text { Presence of foreign } \\
\text { ownership }\end{array}$ & 1.02 & 1.07 & 1.07 & 1.07 & 1.11 & 1.14 \\
\hline $\begin{array}{l}\text { Management separated } \\
\text { from ownership }\end{array}$ & & 1.09 & 1.09 & 1.15 & 1.19 & 1.22 \\
\hline Number of markets & & & 1.01 & 1.07 & 1.10 & 1.16 \\
\hline Firm size & & & & 1.11 & 1.27 & 1.32 \\
\hline Foundation year & & & & & 1.33 & 1.53 \\
\hline Industry & & & & & & 1.41 \\
\hline
\end{tabular}

$\mathrm{N}$ ot e: variance inflation factors for variables which are not used in the regression are set to blank. 
The impact of the relative number of work experience types and categories on the change in the ROSF, 2017-2019

\begin{tabular}{|c|c|c|c|c|}
\hline \multirow{2}{*}{ Variable } & \multicolumn{2}{|c|}{ OLS } & \multicolumn{2}{|c|}{ Probit } \\
\hline & M6 & M6 & M12 & M12 \\
\hline Constant term & -16.144 & -21.166 & + & + \\
\hline Relative number of work experience types & $16.575 * * *$ & & $+* *$ & \\
\hline Relative number of work experience categories & & $20.606 * * *$ & & $+* *$ \\
\hline Deviation of ROSF from the sector average in 2017 & $-0.766 * * *$ & $-0.767 * * *$ & $-* * * *$ & $-* * *$ \\
\hline Presence of foreign ownership & $-48.464 * * *$ & $-48.921 * * *$ & - & - \\
\hline Management separated from ownership & $-14.443 *$ & $-14.303 *$ & - & - \\
\hline Number of markets & 5.757 & 6.599 & - & - \\
\hline Firm size & -1.338 & -1.229 & - & - \\
\hline Foundation year & Yes & Yes & Yes & Yes \\
\hline Industry & Yes & Yes & Yes $* * *$ & Yes $* * *$ \\
\hline Number of observations & 358 & 358 & 358 & 358 \\
\hline Log likelihood & & & -186 & -187 \\
\hline $\mathrm{R}^{2}$ or Pseudo $\mathrm{R}^{2}$ (McFadden) & 0.440 & 0.442 & 0.291 & 0.290 \\
\hline Percent correctly predicted, \% & & & 76.8 & 76.0 \\
\hline Significance of the model & 0.000 & 0.000 & 0.000 & 0.000 \\
\hline
\end{tabular}

N ot es: only signs of the coefficients are given for probit models, the “+” sign means a positive relationship, the "-" sign - a negative; ***, **, * indicate statistical significance at the 1, 5 and 10\% respectively. Variables which are not used in the regression are set to blank. Coefficients of control dummy variables of foundation year and industry are not presented for brevity, "Yes" is written if used. For probit models Log likelihood and percent of correct predictions is given. 
Marginal effects for binary probit models

\begin{tabular}{|c|c|c|c|c|c|c|}
\hline \multirow{2}{*}{ Variable } & \multicolumn{6}{|c|}{ Model } \\
\hline & M7 & M8 & M9 & M10 & M11 & M12 \\
\hline Diversity index & $0.49 *$ & $0.60 * \%$ & $0.62 * *$ & $0.66 * *$ & $0.65 * *$ & $0.71 * *$ \\
\hline $\begin{array}{l}\text { Deviation of ROSF from the } \\
\text { sector average in } 2017\end{array}$ & $-0.01 * * *$ & $-0.01 * * *$ & $-0.01 * * *$ & $-0.01 * * *$ & $-0.01 * * *$ & $-0.01 * * *$ \\
\hline Presence of foreign ownership & -0.15 & -0.13 & -0.13 & -0.14 & -0.15 & -0.17 \\
\hline $\begin{array}{l}\text { Management separated from } \\
\text { ownership }\end{array}$ & & -0.05 & -0.06 & -0.06 & -0.06 & -0.07 \\
\hline Number of markets & & & -0.04 & -0.03 & -0.03 & -0.05 \\
\hline $\begin{array}{l}\text { Firm size (logarithm of the } \\
\text { number of employees in 2017) }\end{array}$ & & & & -0.01 & -0.01 & -0.02 \\
\hline
\end{tabular}

Foundation year 1 - before 1992 - base category

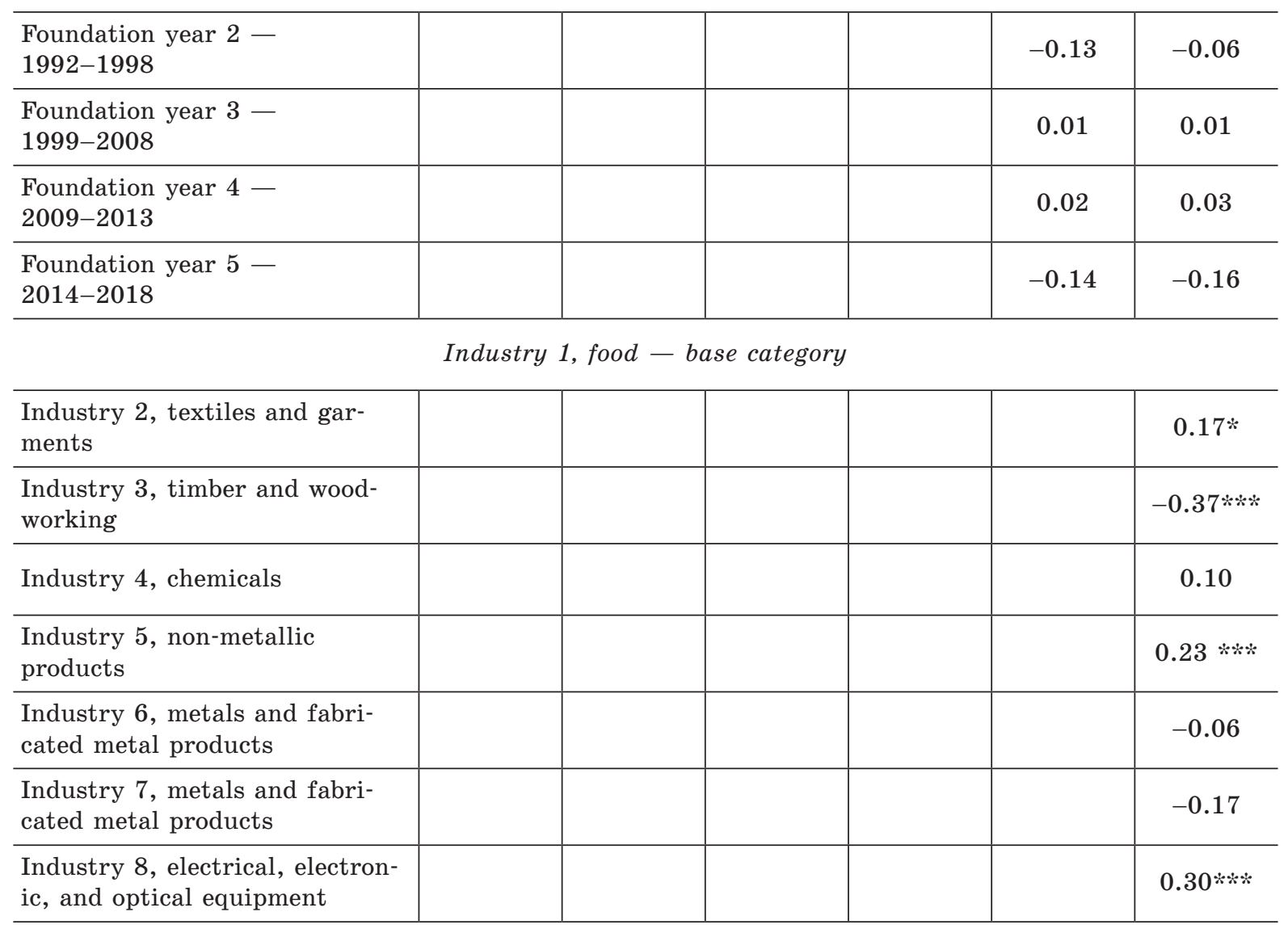


Table 3 (end)

\begin{tabular}{l|c|c|c|c|c|c}
\hline \multirow{2}{*}{ Variable } & \multicolumn{7}{c}{ Model } \\
\cline { 2 - 7 } & M7 & M8 & M9 & M10 & M11 & M12 \\
\hline $\begin{array}{l}\text { Industry 9, transport vehicles } \\
\text { and equipment }\end{array}$ & & & & & & -0.03 \\
\hline
\end{tabular}

N ot es: $* * *, * * *$ indicate statistical significance at the 1,5 and $10 \%$ respectively; marginal effects of variables which are not used in the regression are set to blank. 